\title{
Some economic indicators of coal mining from thin seams
}

DYCHKOVSKYI Roman ${ }^{1,}$, AVDIUSHCHENKO Anna1, b and

\author{
LOZYNSKYI Vasyl ${ }^{1, c}$
}

\author{
${ }^{1}$ State Higher Educational Institution "National Mining University", Karl Marx Avenue, 19, \\ Dnipropetrovsk, Ukraine

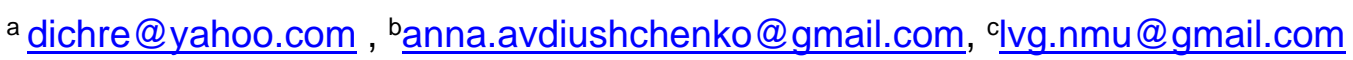

Keywords: geological conditions, wallface operations, investment attractiveness, project profitability.

\begin{abstract}
The method of investment attraction evaluation for the implementation of mining equipment was substantiated. Discounted financial results were taking into account. Pros and cons of chosen method were analyzed. The practical results of the method for definite technical and technology conditions at the SC "Lvivvuhillia" were presented. Values of investment attractiveness taking account monthly costs were determined. The methodology which was worked out by UNIDO were used for conditions of mining equipment implementation for coal reserves exploration of extraction area of mine taking into account cash flow values at the different periods of project realization. It was definite that chosen methodology gave possibility to estimate projects investment attractiveness and could be used for similar projects at the other mining enterprises.
\end{abstract}

\section{Introduction}

An important element in evaluating the effectiveness of working faces in the mines of Ukraine is to create a favorable investment environment and providing appropriate mining equipment. First of all, it concerns highly productive mining equipment in coal mining from thin and very thin coal seams. In this article, the authors suggest ways of setting the initial geometric data to evaluate the stress-strain state of the rock massive and evaluate investment attractiveness of coal extraction project based on the real speeds advance of working face.

\section{Geometrization of simulation parameters of the studied areas}

A major deterrent perform mining operations, includ-ing the implementation of new mining equipment is low awareness of the change of mining and geologi-cal structure and structural excavation sites. This leads to non-standard and emergency situations of the stability of the machinery, reducing the safety of staff in the performance of manufacturing processes, to increase the cost of coal and reduce its competitive-ness in the market.

Highly mechanized extraction requires continuous extraction of coal, which is associated with advance adjusting the power parameters, primarily powered support in the areas of natural and manvariable ten-sion. Correctness of mining surveying and documen-tation of visual reproduction of computer systems makes it possible to advance adaptation of logistics systems to the existing technological situation.

A well-known method of deposits geometrization is a simulation of surfaces contacts primarily minerals using contour spatial location. The development of modern methods of visualization makes it possible significantly expand the ways and forms of represen-tation of all components lithological structure of the studied areas. The system of simulation must as ob-jectively as possible reflect the level of knowledge about mining and geometrical parameters of coal seam. They also have the ability to adjust the overall picture of mining operations in the event of additional data from the wells additional exploration or mining work at meeting new abnormal formations.

In the technical literature ways of geometrization evaluation examined quite low, and the formation of such systems for mining activities is non-available [1,2]. Therefore, to build a mathematical model introduced some ad-justments, relating primarily set coordinate system 
reproducible solids. As an example, consider a ge-ometrization object $\mathrm{P}$, the individual elements in a space, which will be specified in the Cartesian coor-dinate system as $P(i, j, n)$. Except that, (i, $j$, n) re-spectively show its spatial arrangement on the axes X, Y and Z. For the object passed four parameters to be investigated further: the area of lithological contacts, differences in strength characteristics of rock mas-sive, parameters of power support and the coefficient of the lithological structure. Snap of natural values of the investigated area on their location in imitation of reproduction carried out through the following de-pendence in Cartesian coordinate system (1):

$$
\begin{aligned}
& X_{1}=x_{1} \pm x_{0}, Y_{1}=y_{1} \pm y_{0}, Z_{1}=z_{1} \pm z_{0} \\
& X_{2}=x_{2} \pm x_{1}, X_{i}=x_{i} \pm x_{i-1}, Z_{2}=z_{2} \pm z_{1} \\
& X_{i}=x_{i} \pm x_{i-1}, Y_{j}=y_{j} \pm y_{j-1}, Z_{n}=z_{n} \pm z_{n-1}
\end{aligned}
$$

where $X_{1}, X_{2}, \ldots, X_{i}, Y_{1}, Y_{2}, \ldots, Y_{j}, Z_{1}, Z_{2}, \ldots, Z_{n}$ - coordinates of the object in the new (study) coordinate system; $x_{1}, x_{2}, x_{i-1}, \ldots, y_{1}, y_{2}, \ldots, y_{j}, z_{1}, z_{2}, \ldots, z_{n}$ - the actual coordinates of the object being studied;

$x_{0}, y_{0}, z_{0}$ - coordinates of the origin of the new coordinate system.

Each element of the object studied in test point with coordinates $x, y, z$ plane $X O Y$ corresponds to the value $P(i, j) ; X O Z$ planes and $Y O Z-P(i, n)$ and $P(j, n)$. For all stages of the research, we choose a rectangular coordinate system with the beginning of the countdown to the coordinates of all points tested had positive values. Later, these coordinates can be converted to any other system formulas (1), depending on the purpose of the study.

At all stages of objects studied will be seen as simulation the point by three surfaces $P=P(M)$, or as a function of the coordinates $P(i, j) ; R(i, n) ; P(j, n)$. Schedule function of two variables serving some surface, which is based on available points. The overall picture of point's simulation of analyzed variables and, consequently, possible spread curves and surfaces shown in Fig. 1.

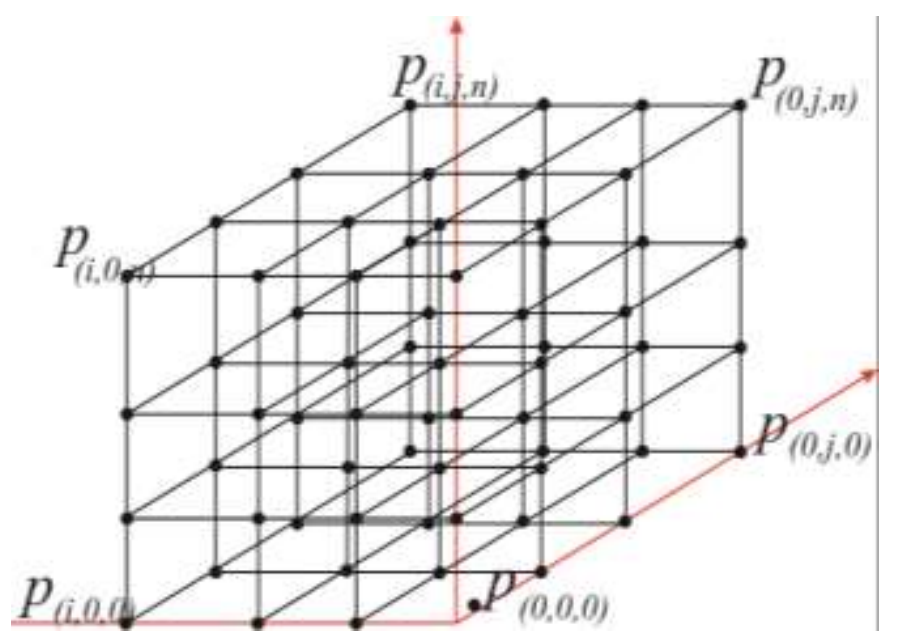

Fig. 1. Spatial mapping of points for the approximation of the objects.

Then we can apply $X_{1}=x_{1} \pm x_{0}$ the proposed methodology [1] on the approximation of the results of simulation. Using two-dimensional regression analysis at a satisfactory correlation coefficient $(R 2)$ obtained surface can be approximated in the space value $P(i, j, n)=0$, that is certain correlation coefficient $R$ can be obtained analytical expression for the function $P P(i, j, n)$. That studied value $R$ is a continuous function of coordinates. Then the properties and character change of this function can be studied by means of mathematical analysis.

At each point of space $M$ (or it part) determined some scalar $u$, which depends on the location of the point, than simulated scalar field $u=u(M)$ or $u=u(x, y, z)$, or $u=\mathrm{u}(\vec{r})$, where $\vec{r}=x \vec{i}+y \vec{j}+z \vec{n}-$ radius vector of the point $M(x, y, z)$. Thus, with respect to the properties studied characteristics are scalar field $P=P(i, j, n)$, defined on a part of the plane bounded, in this case, outside the excavation sites. 
Mathematical concepts of change the shape in any direction in detail is given in [1]. Thus, each point can determine the change in a shape of the object. General system simulation play for specific mining and geological conditions enables a holistic view of components in the "mining technique technological situation - surrounding rocks".

From a practical point of view is performed visualization of each lithological rock differences in three dimensions: along the working face ( $X$-axis) extraction pillar (axis $Y$ ) and too deep rock massive (axis $Z$ ). The next step down basic characteristic zone of the stress-strain state. In the process of coal extraction is changes in the rock massive that easily reproduced using simulation models. They are an effective mechanism for decision-making on the management of mining operations and control of rock pressure.

\section{Mining and geological characteristics of the extraction column}

For further research was selected mining and technological situation at one of the extraction column of mine "Zarichna" SE "Lvivvuhillia". Coal seam $n 7^{v}$ has a simple structure, continuous formation, geological thickness $-0.7 \mathrm{~m}$, extracting seam thickness $-1 \mathrm{~m}$, average $-0.71 \mathrm{~m}$. Coal seam refers to the mark $F$, strength -1.5 . Coal humus, black, clarodurain with inclusions fuzian, poorly fractured. Contacts of coal seam with the enclosing rocks are straight. The coal seam is not liable to spontaneous ignition, dangerous for dust explosions.

The immediate roof of a coal seam for a number of prospecting boreholes represented with shale, dark gray, medium strength and stability, thickness $1.64-3.75 \mathrm{~m}$. The main roof - gray siltstone, horizontally-layered, dense, micaceous. Power up to 5.5 meters.

Step of immediate roof caving:

- primary $\left(l_{i 0}\right)-1.5 \mathrm{~m}$; next $\left(l_{i i}\right)-0.6 \mathrm{~m}$.

Step of main roof collapse:

- primary $\left(l_{m 0}\right)-15-20 \mathrm{~m} ; \quad \operatorname{next}\left(l_{m i}\right) \quad-8-12 \mathrm{~m}$.

Immediate bottom formation represented with siltstones in the upper part with medium strength and stability $\left(P_{2}\right)$, during moisture present tends to swelling. Thickness $0.5-4.7 \mathrm{~m}$. Low lies the sandstone. The lower part of the immediate roof presented with carbonaceous shale, collapse during coal extraction. In places of tectonic dislocation, a layer of carbonaceous shale may reach up to $1 \mathrm{~m}$. On top of contact, shale and carbonaceous shale observed mirror sliding. Shale of the immediate roof is fractured.

The bottom formation represented with sandy shale, sometimes changes with sandstone. Dark gray siltstone at the top of lumpy texture with charred remains of flora. Below the section is layered, micaceous. Seam thickness up to $5.65 \mathrm{~m}$. Tectonically extraction column characterized by average complexity. The intensity of fracturing rocks close the roof make $4-7 \mathrm{fr} / \mathrm{m}$, cracking strike timed to two systems: northeastern (basic) and northwest direction.

For mechanization of extraction works used mechanized complex 1KD90 with sections of the complex 1KD80 combine 1K101. Transportation of extracted coal is carried out with scraper conveyor SP253. To supply the working fluid in the system and its support for the operating pressure of the emulsion used SNT32 oil station.

Extraction pillar outlined with conveyor and boundary drifts. Obtaining a copy of the plan of extraction pillar on mine "Zarichna" SE "Lvivvuhillia" is shown in Fig. 2.

Analysis of strength characteristics of rocks of roof shows that the immediate roof is sufficiently unstable and collapse after stope advance. Based on the deformation characteristics siltstone rocks representing the main roof, changes tensile strength in uniaxial compression within $22.2-$ 29.1 MPa. Above the roof lies a layer of "weak" clay shale (argillite) of tensile strength in uniaxial compression within 21.0-23.4 MPa. Since the deformation characteristics of the rock layer compared to the main rocks of roof, this layer deformed with the main roof. Its power ranges from $3.2 \mathrm{~m}$ on picket PC $0+5$ blowout on the PC $30+6$. Accordingly, during the maximum thickness step of rock collapse reaches $10-15 \mathrm{~m}$. This rock layer may hang or completely collapse at different speeds stope. In the latter case, this situation will form a zone of high pressure and rock will make a significant loading on sections of the mechanized complex. 


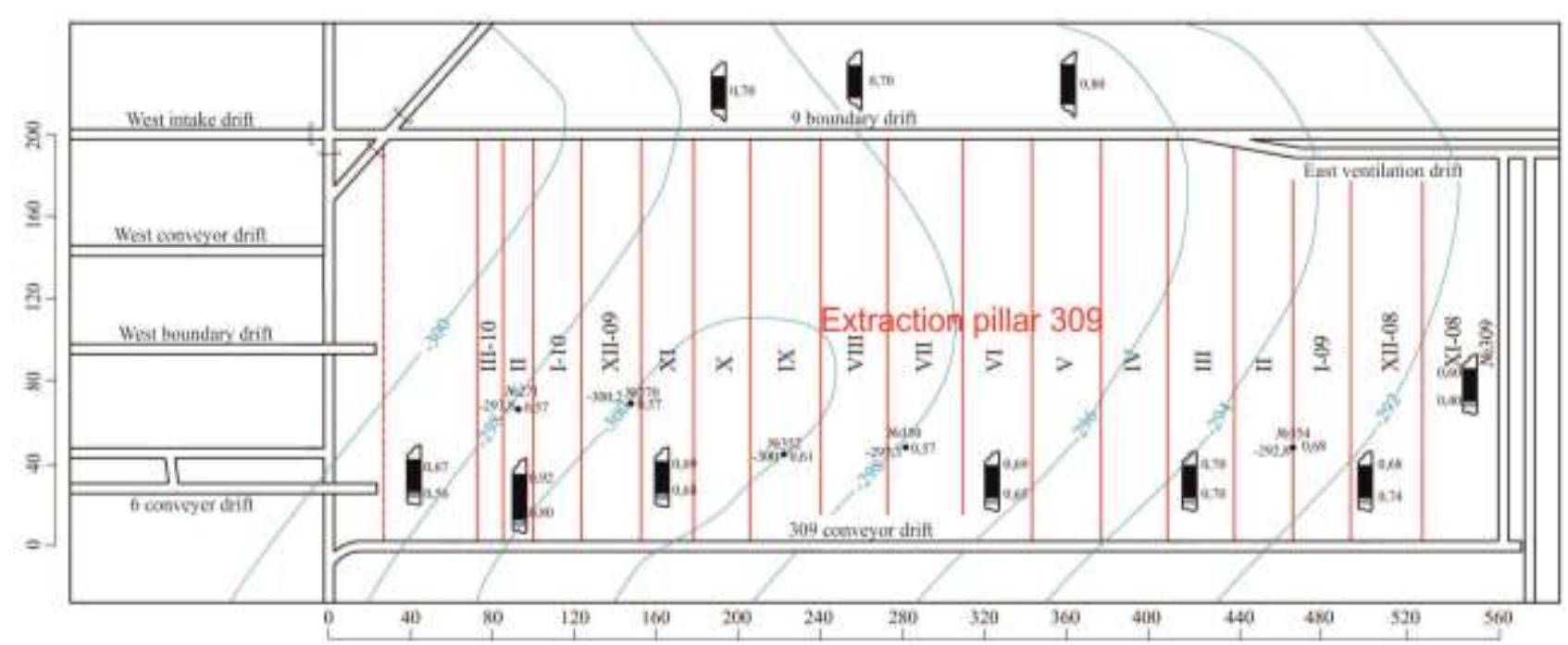

Fig. 2. Obtaining a copy of the plan of extraction pillar on mine "Zarichna" SE "Lvivvuhillia"

Above these rocks lies a layer of rigidity rocks: sandstone and mudstone. The step of these rocks collapses exceed $50 \mathrm{~m}$. The deformation of this layer has elastic and plastic character.

Problem areas of extraction pillar will be the distance from the PC $0+3$ to $\mathrm{PC} 10+7$, where is possible rocks stratification. This is a threat to additional surcharging of powered support.

Analysis of lithological difference shows that the area of extraction pillar PC $0-$ PC $30+6$ provided with the following inequality:

$$
R_{u c 1}<R_{u c 2}<R_{u c 3}>R_{u c 4}<R_{u c 5}
$$

where $R_{u c 1}$ - tensile strength in uniaxial compression of coal seam $n 7^{v} ; R_{u c 2}$ - tensile strength in uniaxial compression of the immediate roof; $R_{u c 3}$ - tensile strength in uniaxial compression of themain roof; $R_{u c 4}$ - tensile strength in uniaxial compression of intermediate rock; $R_{u c 5}$ - tensile strength in uniaxial compression of sandstone.

Basic load on complex mechanical support will occur in based on the main roof displacement as a siltstone and mudstone. Correlation value of rock massive to the thickness of the coal seam $n 7^{\mathrm{v}}$ that taken into the calculation of loads on the section make 3.3-5.3. This condition corresponds to accepted norms determining power parameters of mechanical support.

For lithological and structural features simulation of the rocks structure were imposed Cartesian coordinates volume respectively in the horizontal plane, the length of extraction pillar and the length of working face in vertical - structure of coal and rock massive [3]. To set the thickness of the structural features of coal and rock massive for lithological structure used numerical system simulation and data processing computer software system Excel - 2010. This software product was also used for setting numerical values of received lithological layers.

The complexity of the structure requires a significant variation data, so to simulate on separate lines contact precinct drifts were used polynomials of 6th order. As a result of the approximation was obtained the following mathematical dependence to simulate lines of lithological differences with boundary drifts:

1). $y_{1-1}=0.12211-6.34 E-0.4 x+6.27 E-0.5 x^{2}-2.65 E-0.7 x^{3}+1.13 E-9 x^{4}-2.81 E-12 x^{5}+$ $2.39 E-15 x^{6}$. Authenticity $R^{2}=0.9928$;

2). $y_{2-1}=0.80158+0.00421 x-1.95 E-0.5 x^{2}-1.16 E-07 x^{3}+8.81 E-10 x^{4}-2.61 E-12 x^{5}-$ $2.32 E-15 x^{6}$. Authenticity $R^{2}=0.9935$;

3). $y_{3-1}=0.57513+0.0489 x-4.02 E-04 x^{2}+1.33 E-0.6 x^{3}-9.93 E-10 x^{4}-2.37 E-12 x^{5}+$ $3.12 E-15 x^{6}$. Authenticity $R^{2}=0.9861$;

4). $y 4-1=4.19105-0.03021 x+8.50 E-0.4 x^{2}-6.44 E-0.6 x^{3}+2.24 E-0.3 x^{4}-3.59 E-11 x^{5}+$ $2.15 E-14 x^{6}$. Authenticity $R^{2}=0.9717$; 
5). $y 5-1=5.17867-0.00933 x+7.52 E-05 x^{2}+4.63 E-0.4 x^{3}+1.10 E-0.8 x^{4}-1.62 E-11 x^{5}+$ $8.80 E-15 x^{6}$. Authenticity $R^{2}=0.9745$.

For simulation the line of lithological differences in conveyor drift:

1). $y_{1-2}=2.28833-0.08444 x+0.00131 x^{2}-8.86 E-0.6 x^{3}+2.93 E-0.8 x^{4}-4.61 E-11 x^{5}+$ $2.74 E-14 x^{6}$. Authenticity $R^{2}=0.9941$;

2). $y_{2-2}=2.94141-0.07629 x+0.00121 x^{2}-8.32 E-06 x^{3}+2.8 E-0.8 x^{4}-4.47 E-11 x^{5}+2.68 E-$ $14 x^{6}$. Authenticity $R^{2}=0.9815$;

3). $y_{3-2}=2.71477-0.02301 x+5.64 E-0.4 x^{2}-5.01 E-0.6 x^{3}+1.95 E-8 x^{4}-3.37 E-11 x^{5}+2.13 E$ $-14 x^{6}$. Authenticity $R^{2}=0.9932$;

4). $y_{4-2}=5.97342-0.1097 x+0.00205 x^{2}-1.46 E-0.5 x^{3}+4.93 E-0.8 x^{4}-7.76 E-11 x^{5}+4.59 E-$ $14 x^{6}$. Authenticity $R^{2}=0.9842$;

5). $y_{5-2}=7.38545-0.02667 x+4.84 E-0.4 x^{2}-3.65 E-0.6 x^{3}+1.29 E-0.8 x^{4}-2.07 E-11 \mathrm{x}^{5}+$ $1.22 E-14 x^{6}$. Authenticity $R^{2}=0.9854$.

The value of " $x$ " indicates an approximation line of contact length extraction pillar, numerical value - coefficient that takes into account the geological structure according boundary and conveyor drifts. Area of individual layers of lithological differences within the ranks of extraction pillar can be determined by the following mathematical expressions:

$$
\begin{array}{rlrl}
P_{1-1} & =\int_{0}^{560} f\left(y_{2-1}-y_{1-1}\right) d x ; & P_{1-2} & =\int_{0}^{560} f\left(y_{2-2}-y_{1-2}\right) d x ; \\
P_{2-1} & =\int_{0}^{560} f\left(y_{3-1}-y_{2-1}\right) d x ; & P_{2-2} & =\int_{0}^{560} f\left(y_{3-2}-y_{2-2}\right) d x ; \\
P_{3-1} & =\int_{0}^{560} f\left(y_{4-1}-y_{3-1}\right) d x ; & =\int_{0}^{560} f\left(y_{4-2}-y_{3-2}\right) d x ; \\
P_{4-1} & =\int_{0}^{560} f\left(y_{5-1}-y_{4-1}\right) d x ; & P_{4-2} & =\int_{0}^{560} f\left(y_{5-2}-y_{4-2}\right) d x .
\end{array}
$$

\section{Research results of rock pressure manifestation in the working area}

This research aimed to establish the dependency of rock pressure during longwall advance. This is done by determining the stress experimentally - analytical methods described in [4]. The manifestation of stress over time is a loading on power support on stope corresponding to the pressure of the working fluid in the system power sections. On the first phase is established an area of minefield gradient stresses [5]. They correspond to areas of mining, which took place in the stable lateral movement of rocks and they are out beyond the raised or reduced pressure. Change displacement leads to adequate change stresses. The ratio of the received values to gradient show increase stresses on the test site extraction column.

Overburden recasting in the workspace defined by measuring studs SUI -2 with nozzles and surveying tape. Analysis of the magnitude of the lateral load of rocks performed using mine gauges and setting pressure in riser's mechanical support.

Detailed have been studied mining and geological conditions of coal seam bedding: variations in the thickness and angle of the seam, physical and mechanical properties of coal and rock side. On this basis, developed recommendations on features performance processes in the long wall and provided recommendations for control rock pressure. 
It can be concluded that the primary landing distance roof (d1) during thin and very thin coal seam extraction under conditions of week rocks of roof (roof: $B 2, B 3, A 1, A 2$ ) within the length of the longwall from 150 to $30 \mathrm{~m}$ defined by linear dependence, which in general is expressed by the following dependence:

$$
d l=k n+c,
$$

where $k, c$-empirical coefficients that characterize the geological structure of rock massive;

$k$ - tangent deviation of rocks (determined on the basis of Coulomb-Mohr);

$c$ - coefficient characterizing the strength and power of layer stiffness (in the main roof rocks).

\section{Choice the methods of economic evaluation}

By definition, technical equipment of coal extraction in pillar column and technological support of extraction represents high-budget investment project. Accordingly, for investment it is necessary to comprehensively assess the feasibility of the initiative. The owners of the rights to extract these reserves and foreign investors comprehensively carry out economic analysis of the project for investing in the implementation of the proposed solutions. Therefore, the authors give special attention to the selection method of the present economic assessment of the project.

Almost all currently available mathematical approaches and mechanisms for assessing the investment attractiveness of mining projects and related industries based on the methodology developed by the Committee of Industrial Development of United Nations organization (UNIDO United Nations Industrial Development Organization) in the 70's of last century. It allows you to gather all necessary information to carry out the forecast cash flows and accordingly evaluate the project using quantitative indicators. According to this technique, can be done and complete a preliminary feasibility study and financial initiatives to establish the risks of their implementation [6]. Methods of implementation for similar geological conditions are given in [7].

\section{Calculation data}

Given the advantages and disadvantages of the above factors, to determine the parameters of the investment attractiveness of the proposed technical and technological solutions for the excavation column of mines SE "Lvivvuhillia" choose three parameters of estimation:

- Discounted payback period (DPP).

- Net present value (NPV).

- The index of profitability of the project (IP).

It should be noted that the calculation of investment attractiveness of the investee was carried out the planned and actual indicators (Table 1 and 2, Fig. 3).

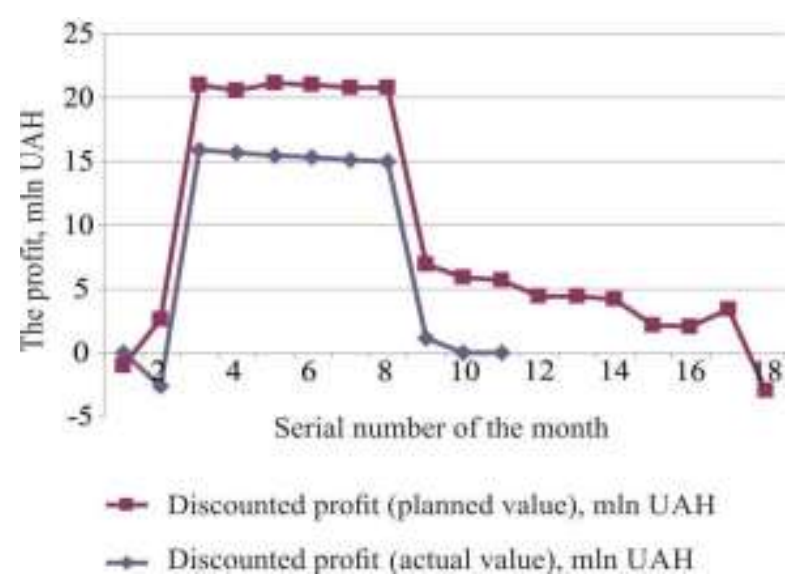

Fig. 3. Changes in net discounted profit project (planned and actual values) 
Table 1. Planned indicators of income and expenditure for the extraction column of mines SE "Lvivvuhillia"

\begin{tabular}{|l|c|c|c|c|c|c|c|c|}
\hline \multirow{2}{*}{\multicolumn{1}{|c|}{ Indicators }} & \multicolumn{7}{|c|}{$\begin{array}{c}\text { Project implementation period, } \\
\text { the serial number of the month }\end{array}$} \\
\cline { 2 - 10 } & 1 & 2 & 3 & 4 & 5 & 6 & 7 & 8 \\
\hline Profit*, mln UAH & 6.8 & 19.7 & 19.7 & 19.7 & 19.7 & 19.7 & 19.7 & 12.6 \\
\hline Costs**, mln UAH & 9.4 & 3.6 & 3.6 & 3.6 & 3.6 & 3.6 & 3.6 & 11.3 \\
\hline Net profit / loss***, mln UAH & -2.6 & 16.1 & 16.1 & 16.1 & 16.1 & 16.1 & 16.1 & 1.3 \\
\hline Resource Net profit / loss, mln UAH & -2.6 & 13.5 & 29.6 & 45.7 & 61.8 & 77.9 & 94.0 & 95.3 \\
\hline
\end{tabular}

*137.6 mln. UAH - total profit; **61.7 mln. UAH - planned expenditures: $19.4 \mathrm{mln}$. UAH - the cost of fixed assets (mechanized complex); $42.3 \mathrm{mln}$. UAH - current expenditures including the introduction of mechanized complex operation and withdrawal from it; ***75.9 mln. UAH - planned profit.

Table 2. Actual income and expenditure for the extraction column of mines SE "Lvivvuhillia"

\begin{tabular}{|l|c|c|c|c|c|c|c|c|c|}
\hline \multicolumn{1}{|c|}{ Serial number of the month } & 1 & 2 & 3 & 4 & 5 & 6 & 7 & 8 & 9 \\
\hline Profit*, mln UAH & 8.4 & 8.1 & 7.8 & 7.7 & 8.1 & 8.1 & 8 & 8.1 & 7.7 \\
\hline Costs**, mln UAH & 9.4 & 2.8 & 2.6 & 2.6 & 2.8 & 2.7 & 2.7 & 2.7 & 2.5 \\
\hline Net profit / loss***,mln UAH & -1.0 & 5.3 & 5.2 & 5.1 & 5.3 & 5.4 & 5.3 & 5.4 & 5.2 \\
\hline $\begin{array}{l}\text { Resource Net profit / loss, } \\
\text { mln UAH }\end{array}$ & -1.0 & 4.3 & 9.5 & 14.6 & 19.9 & 25.3 & 30.6 & 36 & 41.2 \\
\hline Serial number of the month & 10 & 11 & 12 & 13 & 14 & 15 & 16 & 17 & 18 \\
\hline Profit*, mln UAH & 7.9 & 7.2 & 7.3 & 7.2 & 6.9 & 4.4 & 4.3 & 6.6 & 7.6 \\
\hline Costs**, mln UAH & 2.6 & 2.2 & 2.2 & 2.1 & 2.0 & 1.8 & 1.8 & 2.4 & 11.3 \\
\hline $\begin{array}{l}\text { Net profit / loss***, mln } \\
\text { UAH }\end{array}$ & 5.3 & 5.0 & 5.1 & 5.1 & 4.9 & 2.6 & 2.5 & 4.2 & -3.7 \\
\hline $\begin{array}{l}\text { Resource Net profit / loss, } \\
\text { mln UAH }\end{array}$ & 46.5 & 51.5 & 56.6 & 61.7 & 66.6 & 69.2 & 71.7 & 75.9 & 72.2 \\
\hline
\end{tabular}

*131.4 mln UAH - total profit; **78.6 mln. UAH - planned expenditures: $19.4 \mathrm{mln}$. UAH - the cost of fixed assets (mechanized complex); $59.2 \mathrm{mln}$. UAH - current expenditures including the introduction of mechanized complex operation and withdrawal from it; ***52.8 mln. UAH - planned profit.

Table 3. Net present value of project (planned value) for the extraction column of mines SE "Lvivvuhillia"

\begin{tabular}{lcccccccccc}
$\begin{array}{l}\text { Serial number of the } \\
\text { month }\end{array}$ & 1 & 2 & 3 & 4 & 5 & 6 & 7 & 8 & 9 & 10 \\
\hline $\begin{array}{l}\text { Discount rate (rate of } \\
\text { eturn - 15\%) }\end{array}$ & 1.00 & 0.988 & 0.975 & 0.963 & 0.951 & 0.939 & 0.928 & 0.917 & 0.905 & 0.894 \\
$\begin{array}{l}\text { Discounted profit / loss, } \\
\text { ln UAH }\end{array}$ & -2.60 & 15.90 & 15.70 & 15.51 & 15.31 & 15.13 & 14.94 & 1.19 & -2.60 & 15.90 \\
$\begin{array}{l}\text { Resource discounted } \\
\text { rofit / loss, mln UAH }\end{array}$ & -2.60 & 13.30 & 29.01 & 44.52 & 59.84 & 74.97 & 89.91 & 91.10 & -2.60 & 13.30 \\
\hline
\end{tabular}

Table 4. Net present value of project (actual value) for the extraction column of mines SE "Lvivvuhillia"

\begin{tabular}{|l|c|c|c|c|c|c|c|c|c|}
\hline \multicolumn{1}{|c|}{$\begin{array}{c}\text { Serial number of the } \\
\text { month }\end{array}$} & 1 & 2 & 3 & 4 & 5 & 6 & 7 & 8 & 9 \\
\hline $\begin{array}{l}\text { Discount rate (rate of } \\
\text { return - 15\%) }\end{array}$ & 1.00 & 0.988 & 0.975 & 0.963 & 0.952 & 0.94 & 0.928 & 0.917 & 0.905 \\
\hline $\begin{array}{l}\text { Discounted profit / loss. } \\
\text { mln UAH }\end{array}$ & -1.00 & 5.23 & 5.07 & 4.91 & 5.57 & 5.75 & 5.71 & 5.89 & 5.74 \\
\hline $\begin{array}{l}\text { Resource discounted } \\
\text { profit / loss. mln UAH }\end{array}$ & -1.00 & 4.23 & 9.31 & 14.22 & 19.79 & 25.54 & 31.25 & 37.14 & 42.88 \\
\hline
\end{tabular}




\begin{tabular}{|l|c|c|c|c|c|c|c|c|c|}
\hline $\begin{array}{l}\text { Serial number of the } \\
\text { month }\end{array}$ & 10 & 11 & 12 & 13 & 14 & 15 & 16 & 17 & 18 \\
\hline $\begin{array}{l}\text { Discount rate (rate of } \\
\text { return - 15\%) }\end{array}$ & 0.894 & 0.883 & 0.872 & 0.862 & 0.851 & 0.84 & 0.83 & 0.819 & 0.809 \\
\hline $\begin{array}{l}\text { Discounted profit / loss. } \\
\text { mln UAH }\end{array}$ & 5.93 & 5.66 & 4.45 & 4.39 & 4.17 & 2.18 & 2.07 & 3.44 & -2.99 \\
\hline $\begin{array}{l}\text { Resource discounted } \\
\text { profit / loss. mln UAH }\end{array}$ & 48.81 & 54.46 & 58.92 & 63.31 & 67.48 & 69.67 & 71.74 & 75.18 & 72.19 \\
\hline
\end{tabular}

\section{Conclusions}

The actual rate of total discounted profit was almost 1.3 times lower than planned. NPV according to forecast and actual values are positive and the decision to invest should be positive in both cases. Variation of the index return is similar to changing the values of NPV, as the calculation of the criteria taken into account the value of the overall index NPV in relation to the initial capital investment (the cost of the mechanized complex). Payback period is the same for planned and actual values and is 2 months, but that in this case there is a major disadvantage of this method, namely that remain out of sight profitability of the project beyond the payback period. Therefore, this criterion should not be taken into account when deciding on the investment project in a given situation.

Taking into consideration the economic evaluation of the project, we can conclude that the proposed technical and technological solutions for mining in extraction column of mines SE "Lvivvuhillia" are positive both for planned and actual data. Further research is planned similar economic evaluation of investment projects for mining companies in Ukraine and foreign mines. Special attention will be given to the economic evaluation of the technology implementation of a new level. This work is accompanied with significant financial investments and associated with financial risks.

\section{Bibliography}

[1] Berestneva, O.G., Berestneva, E.A., Muratov E.A. \& Yankovskaya A.E. 2003. Analysis of the structure of multidimensional data by the local geometry. Bulletin of the Tomsk Polytechnic University, 3, 19-23.

[2] Skvortsov, A.V. 2002. Algorithms analysis triangulation surface model. Visnyk VSU, 275: 95-98.

[3] Falshtyns'kyy, V., Dychkovs'kyy, R., Lozyns'kyy, V., \& Saik, P. (2013). Justification of the gasification channel length in underground gas generator. Mining of Mineral Deposits, 125-132. http://dx.doi.org/10.1201/b16354-23

[4] Gritsko, G.I \& Vlasenko, B.V. (1975). General principles for evaluating the stressed state of experimental and analytical method of rock mechanics. Analytical methods and computer technology in rock mechanics. 109-116.

[5] Falshtynskyy, V., Dychkovskyy, R., Lozynskyy, V., \& Saik, P. (2012). New method for justification the technological parameters of coal gasification in the test setting. School of Underground Mining 2012, 201-208. http://dx.doi.org/10.1201/b13157-35

[6] Bayura, D. (2002). The methodology of UNIDO. Ukrainian Investment Newspaper. 49, (321).

[7] Lozynskyi, V.H., Dychkovskyi, R.O., Falshtynskyi, V.S., \& Saik, P.B. (2015). Revisiting possibility to cross disjunctive geological faults by underground gasifier. Naukovyi Visnyk Natsionalnoho Hirnychoho Universytetu, (4), 22-27. 